\title{
OWNERSHIP STRUCTURE, FREE CASH FLOW, ASSET STRUCTURE AND DIVIDEND POLICY ON DEBT POLICY
}

\author{
Nirina Tahir ${ }^{1}$, Asrudin Hormati ${ }^{2}$ Zainuddin $^{3}$ \\ 1,2,3 Accounting Program, Economics and Business Faculty, Universitas Khairun, Jl. Jusuf Abdulrahman, \\ Ternate, 97719, Indonesia
}

Corresponding e-mail: zainudin@unkhair.ac.id

\begin{abstract}
This study is designed based on problems related to debt policy. The debt policy in every company has a direct effect on the financial position. The use of debt that which too high provides great risk, but if the companies are able to manage debt properly; then the use of debt shall increase profits for shareholders. The purpose of this study was to determine and analyze the effects of managerial ownership, institutional ownership, free cash flow, assets structure, and dividend policy on companies indexed LQ-45 wich listed on the Indonesia Stock Exchange. The sampling technique of this study is purposive sampling which produced 85 observations. This study uses secondary data in the form of annual reports. The tool of analysis of this study is multiple regression with support of statistical package for social scientists (SPSS) software. The results show that: (1) managerial ownership has no effect on debt policy; (2) institutional ownership has a negative effect on debt policy; (3) free cash flow has a negative effect on debt policy; (4) assets structure has a negative effect on debt policy and (5) dividend policy has no effect on debt policy.

Keywords: ownership structure; free cash flow; asset structure; dividend policy; debt policy JEL Clasification: G32, G35
\end{abstract}

Article info:

Received 8 February 2020

Revised 14 March 2020

Accepted 8 May 2020

Available online 8 May 2020

\section{INTRODUCTION}

The development of the economic condition of the business world, both large and small companies are currently experiencing increasingly rapid and sharp competition. These conditions are challenges and opportunities for companies to develop their business in the global market. But on its way, the business world experienced various obstacles, which is problem of funding. Corporate funding decisions are important decisions which considering the right capital structure and also relate to their survival later. In the increasingly fierce competition in the business world, every company is able to increase profits and value of the company in public. In managing its financial functions, one element to consider is how much the company is able to meet the funding needs that will be used to operate and develop its business. These funds can be obtained from various sources, namely internal funds and external funds. Internal company funds are funds that can be obtained from within the company or funds that are self-generated by the company such as current income, retained earnings, and share capital, while external funds are funds sourced from outside the company, such as debt, meaning long-term debt and debt short-term (Akbar and Ruzikna, 2016).

This study uses companies indexed in LQ-45 Index wich listed on the Indonesia Stock Exchange (IDX) on period of 2014 till 2018. The LQ-45 Index Company is chosen because it is seen from the funding problems within the company. Funding of the companies causes the market capitalization of 45 shares that are the most liquid and have a large capitalization 
value. This is because the LQ-45 index company uses 45 shares selected based on stock trading liquidity and adjusted to certain criteria. So that researchers are interested in researching in the LQ-45 Index company.

\section{LITERATURE REVIEWS}

Agency theory. Agency theory called the principalas shareholders and what is meant by the agent is the management that manages the company. In financial management, the company's main goal is to maximize shareholder wealth. On this reason, managers appointed by shareholders must act in the interests of shareholders. Agency theory initially began to develop in the 1960s, at which time the main emphasis of economists was to explore the distribution of risk among (risk sharing) a number of individuals or groups with an interest in economic activity. The problem that arises in the distribution of risk is the difference in attitude over risk itself from a number of interested parties. This happens because the main concept from this perspective views the organization asnexus of contract (Jensen and Meckling, 1976). The contract in question is a contract that occurs between the company's investors (principals) and company managers (agents). This studies of Jensen and Meckling (1976), Watts and Zimmerman (1990) and Setiana and Sibagariang (2013) states that the financial statements prepared with accounting numbers are expected to minimize conflicts between the parties concerned. On financial informations reported by agents as performance accountability then principals assess, measure and monitor the extent to which agents work to improve their welfare and as a basis for compensating agents. Another cause of conflict between managers and shareholders is funding decisions. Shareholders only care about the systematic risk of company shares because they invest in a well diversified portfolio. However, managers in contrast are more concerned with overall corporate risk.

Owner structure. According to Sugiarto (2009), ownership structure is a comparison of the number of shares owned by investors, or in other words the ownership structure is the proportion of institutional ownership and managerial ownership in the ownership of company shares.

Managerial ownership. Managerial ownership is the percentage of share ownership by management that actively participates in corporate decision making (such as Directors and Commissioners). In other words, managerial ownership is a situation where the manager owns the company's shares or managers as well as the company's shareholders. Managers have a tendency to use high debt not on the basis of maximizing the value of the company but in their opportunistic interests. This can be seen through the selection of high-risk projects. This will cause an increase in the company's interest expense because the risk of bankruptcy is higher which resulting in higher debt agency costs. Increasing agency costs will affect the decline in value of the company (Setiana and Sibagariang, 2013). According to Wahidahwati (2002), this agency problem occurs when the proportion of managers' ownership of company shares is less than $100 \%$, so managers tend to act to pursue their own interests and are not based on maximizing value in funding decisions. Managerial ownership is interesting if it is related to agency theory. In framework of agency theory, the relationship between managers and shareholders is described as the relationship between agents and principals. Agents are mandated by the principal to conduct business in the interests of the principal. Managers as agents and shareholders as principals.

Institusional ownership. According to Anggraini (2011), institutional ownership is ownership of shares of companies which are majority owned by institutions or institutions (such as insurance companies, banks, investment companies, asset management and other institutional ownership). According to Surya and Rahayuningsih (2012), an institution can have a majority share because the institution has more resources than other shareholders who are generally individuals. High institutional ownership will cause management to be careful 
in using debt because if debt is used to finance high-risk projects, it can cause shareholders to sell their shares. According Crutchley and Hansen (1989), institutional ownership can also reduce agency costs, because with effective monitoring by institutional parties, debt usage decreases. Indahningrum and Handayani (2009) state that institutional ownership has a direct influence on the prediction of a company's debt policy. The higher the institutional ownership, the higher the company's debt policy.

Free cash flow. Free cash flow is the excess cash needed to fund all projects that have a positive net present value. This free cash flow can cause conflicts of interest between managers and shareholders. Management usually prefers to reinvest this fund in projects that can generate profits because this alternative will increase the incentives it receives. On the other hand, shareholders expect the remaining funds to be distributed so that it will improve the welfare of shareholdersto (Jensen, 1986).

Assets structure. Asset structure is determining the amount of allocation for each component of assets, both current assets and fixed assets (Syamsuddin, 2009). The composition of tangible fixed assets of a large number of companies will have the opportunity to get additional capital with debt, because fixed assets can be used as collateral to get debt (Sitanggang, 2013). The higher the structure of the company's assets shows the higher ability of the company to be able to guarantee the long-term debt that is borrowed.

Dividend policy. According to Rozeff (1982), dividend payments are part of monitoring company activities by the head of management as an agent. Companies will tend to pay higher dividends if management has a lower proportion of shares.

Debt policy. According to Setiana and Sibagariang (2013), the company's debt policy is a policy taken by management to obtain funding sources (funds) from third parties to finance the company's operational activities. This is closely related to the capital structure chosen by the company. Capital structure is the balance between foreign capital or debt with own capital. The company owner prefers the company to use debt at a certain level so that the expectations of the company owner can be achieved. In addition, the behavior of company managers and commissioners can also be controlled. The debt policy is also a company policy to utilize external funding facilities. Debt is all companies obligations to other parties that have not been fulfilled, where this debt is a source of funds or company capital that comes from creditors (Setiana and Sibagariang, 2013).

\section{RESEARCH METHOD}

Data. The type of data used in this study is sourced from financial statements (annual reports) company publications LQ-45 Index listed on the Indonesia Stock Exchange consisting of statements of financial position, income statements, and notes to the annual LQ45 reports on period of 2014 till 2018. Data collection techniques used in this study are carried out in the following ways:

1. Documentation, namely the collection of data available on the object of research, in this case the company's annual financial statement documents listed on period 2014 to 2018 in Indonesia Stock Exchange (or BEI).

2. Literature studies are carried out to complement the data obtained from previous research. Additional data obtained from textbooks, scientific journals, results of previous studies and other scientific works that are relevant to the problem to be examined.

Sample. The sampling used in this study is probability sampling with sampling techniques using purposive sampling where the determination of the sample is based on certain criteria. The number of samples in this study consisted of 85 observation companies from LQ 45 companies listed on the Indonesia Stock Exchange.

Method of analysis. Based on the hypothesis in this study, the data analysis method used is quantitative analysis. Quantitative analysis is a measurement used in research with a 
certain number of units or expressed in numbers. This analysis includes data processing, organizing data and finding the results of data testing conducted in this study is to use multiple linear regression models.

\section{Measurement of variables}

Managerial ownership. Managerial ownership is the level of management share ownership that actively participates in decision making, for example directors and commissioners (Wahidahwati, 2002). The formula of managerial ownership is:

$$
\text { MOWN }=\frac{\text { Total management share }}{\text { Total share }} \times 100 \%
$$

Institutional ownership. Institutional ownership is the percentage of share ownership by institutional investors such as investment companies, banks, insurance companies and ownership of institutions and other companies. Institutional ownership has an important role in the company because it can control management with more optimal supervision (Indahningrum and Handayani, 2009). Institutional ownership is formulated as follows:

$$
\text { IOWN }=\frac{\text { Total institutional share }}{\text { Total share }} \times 100 \%
$$

Free cash flow. Free cash flow is cash flow that describes how much cash can be generated by the company after spending some money to maintain and develop its assets. Following Guinan (2010), the free cash flow is calculated formula as follows:

$$
\mathrm{FCF}=\frac{\text { Operation cash flow }- \text { Capital expenditure }}{\text { Total assets }}
$$

The formula for calculating or getting the value of capital expenditure, namely: (1) value of changes in assets (total previous assets minus total current assets); (2) value of change in liabilities (total previous liabilities minus total current liabilities); and (3) value of capital expenditure (value of changes in assets minus value of changes in liabilities).

Assets structure. Asset structure is the determination of how much the allocation of funds for each component of assets, both in fixed assets and current assets (Syamsuddin, 2009). The structure of assets is formulated as follows:

$$
\text { AST }=\frac{\text { Fixed asset }}{\text { Total assets }} \times 100 \%
$$

Dividend policy. Dividend policy is a decision whether profits derived by a company will be distributed to shareholders in the form of dividends or will be maintained to increase capital (Atmaja, 2008). Dividend policy measurement is carried out using the following formula:

$$
\text { DPR }=\frac{\text { Dividend per share }}{\text { Earnings per share }}
$$

Debt policy. Debt policy is any type of debt created or created by a company, both long-term and long-term debt (Nasser, 2008). Debt policy is measured by the ratio of debt to assets (DAR), which is a comparison between total long-term debt and total assets. DAR can be formulated as follows: 


\section{RESULTS AND DISCUSSIONS}

$$
\text { DAR }=\frac{\text { Total liabilities }}{\text { Total assets }} \times 100 \%
$$

\section{1. $\quad$ Results}

Hypothesis testing in this study was carried out by multiple linear regression analysis. Multiple linear regression analysis is used to examine the effect of ownership structure, free cash flow, asset structure, and dividend policy on debt policy. Table 1 presents the resultsmultiple linear regression analysis as follows:

\section{Table 4.1. Result of multiple linier regression}

\begin{tabular}{|c|c|c|c|c|}
\hline Dependend Variable & Independend Variable & B & $\mathbf{t}$ & Sig. \\
\hline \multirow{5}{*}{ Debt Policy } & Managerial ownership (X1) & 1.579 & 0.494 & 0.623 \\
\hline & Institutional ownership (X2) & -0.450 & -2.339 & 0.022 \\
\hline & Free cash flow (X3) & -0.861 & -4.448 & 0.000 \\
\hline & Assets structure (X4) & -0.626 & -5.906 & 0.000 \\
\hline & Dividend policy (X5) & 0.033 & 0.540 & 0.591 \\
\hline Constant & 1.058 & & & \\
\hline $\mathrm{R}$ & : 0.826 & & & \\
\hline R Square & $: 0.683$ & & & \\
\hline Adjust. R Squared & $: 0.663$ & & & \\
\hline $\mathrm{F}$ & : 34.032 & & & \\
\hline Sig. F & : 0.000 & & & \\
\hline $\mathrm{N}$ & $: 85$ & & & \\
\hline
\end{tabular}

Source: dataset processed, 2020

Table 4.1 shows that the effects of managerial ownership, institutional ownership, free cash flow, asset structure, and dividend policy on debt policy can be made in following equation:

$$
\mathrm{Y}=1,058+1.579 \mathrm{X} 1-0,450 \mathrm{X} 2-0,861 \mathrm{X} 3-0,626 \mathrm{X} 4+0,033 \mathrm{X} 5+\mathrm{e}
$$

This equation can be explained as follows:

1. The value of the constant (a) is 1.058. That is, if managerial ownership, institutional ownership, the free cash flow, assets structure and dividend policy are 0 , then the debt policy is positive at 1.058 .

2. The managerial ownership variable has a positive directional regression coefficient of 1.579. this illustrates that if the managerial ownership variable is 1 percent, the debt policy has a positive value of 1.579 assuming the other independent variables are considered constant. The $t$ value of 0.494 with a significance of 0.623 whose value is greater than the significance level $(\alpha)=5 \%$ or 0.05 . These results indicate that managerial ownership partially has no effect on the debt policy. Thus H1 was rejected.

3. The institutional ownership variable has a negative directional regression coefficient of 0,450 . This illustrates that if there is an increase in the institutional ownership variable by 1 percent, the debt policy will decrease by $-0,450$ assuming the other independent variables are considered constant. The tvalue of 2.3339 with a significance of 0.022 whose value is smaller than the level of significance $(\alpha)=5 \%$ or 0.05 . These results indicate that partial institutional ownership has a negative effect on the debt policy. Thus $\mathrm{H} 2$ is accepted.

4. The free cash flow variable has a negative directional regression coefficient of -0.861 . It illustrates that if the increase in the free cash flow variable is 1 percent, the debt policy 
will decrease by $-0,861$ assuming the other independent variables are considered constant. The $t$ value of $-4,448$ with a significance of 0,000 whose value is smaller than the level of significance $(\alpha)=5 \%$ or 0.05 . These results indicate that some of the free cash flow has a negative effect on debt policy. Thus $\mathrm{H} 3$ is accepted.

5. The assets structure variable has a negative directional regression coefficient of -0.662 . This illustrates that if there is an increase in the assets structure variable by 1 percent, the debt policy will decrease by $-0,626$ assuming the other independent variables are considered constant. The $t$ value of $-5,906$ with a significance of 0,000 whose value is smaller than the level of significance $(\alpha)=5 \%$ or 0.05 . These results indicate that the assets structure partially has a negative effect on the debt policy. Thus H4 is accepted.

6. Dividend policy variable have a positive directional regression coefficient that is equal to 0.033. It illustrates that if the dividend policy variable is 1 percent, then the debt policy has a positive value of 0.033 assuming the other independent variables are considered constant. The t value of 0.540 with a significance of 0.591 whose value is greater than the significance level $(\alpha)=5 \%$ or 0.05 . These results indicate that the dividend policy partially has no effect on the debt policy. Thus H5 is rejected.

\subsection{Discussions}

The effect of management ownership on debt policy. The result of this study indicates managerial ownership has no effect on debt policy which means that managerial ownership is not an aspect affecting debt policy. Managerial ownership measures do not guarantee changes in debt policy. This study is in line with research conducted by Mardiyati et al., (2018) which states that size of managerial shareholding does not affect debt policy.

The effect of institutional ownership on debt policy. The result of this study indicates that institutional ownership has a negative effect on debt policy which means greater institutional ownership can reduce debt policy in companies. This study is in line with study of Warapsari and Suaryana (2016) which state that increased share ownership by institutions can offset the need for debt, and Nafisaet et al. (2016) which state that increasing percentage of share ownership by an institution will reduce the company's debt policy.

The effect of free cash flow on debt policy. The result of this study indicates that free cash flow has a negative effect on debt policy which means that the higher the free cash flow then lower the debt policy. This study in line with Putri and Nasir (2006) which states that after a crisis, managers try to improve company stability by using free cash flow to pay off debt, because too high debt increases the risk of bankruptcy. Debt reduction is expected to benefit from investment and the company's operations in the following year are not only used to pay debts but can also be used for re-investment purposes.

The effect of assets structure on debt policy. The result of this study indicates that assets structure has a negative effect on debt policy which means that higher the level of assets structure of a company will reduced debt usage. This study in line with Sinaga (2017) which states that the assets structure negatively affects the debt policy because the company has larger current assets to fund the company's operations.

The effect of dividend policy on debt policy. The result of this study indicates that dividend policy does not affect debt policy. This means that dividend policy cannot be a factor in determining debt policy. High dividend policy does not necessarily have an impact on corporate debt policy. This study in line with Djabid (2009) which states that the insignificant research results can be another factor that affects it for example the company applies a stable dividend distribution policy where the company continues to pay dividends even though the company loses or has debt. Dividend policy does not affect debt policy because investors and creditors tend have more attention to level of company profits which comes from its stock price rather than decision on dividend distribution. 


\section{CONCLUSION}

This study concludes that: (1) managerial ownership has no effect on debt policy as managerial ownership measures does not guarantee changes in debt policy; (2) institutional ownership has a negative effect on debt policy as greater the institutional ownership tend lowering debt usage in the company; (3) free cash flow has a negative effect on debt policy as higher the free cash flow then lower the debt usage; (4) assets structure has a negative effect on debt policy as higher level of asset structure of a company will decrease debt usage; and (5) dividend policy has no effect on debt policy as this policy is an insignificant factor for determining debt policy. Considering the limitations, then this study suggests that the next studies expand the object of research, adding the scope of the number of samples to obtain more explanation over the condition of debt policy. This study also suggests that further studies to develop other independent variables to explain the behavior of company debt policies, such as profitability, investment opportunity sets or other non-financial variables.

\section{REFERENCES}

Akbar, D., \& Ruzikna. (2016). pengaruh struktur kepemilikan, free cash flow, struktur aset, dan kebijakan dividen terhadap kebijakan hutang pada perusahaan sub sector otomotif dan komponen yang terdaftar di Bursa Efek Indonesia (BEI). Jurnal Online mahasiswa Fakultas Ilmu Sosial dan Politik, 4(2), 1-11. https://jom.unri.ac.id/index.php/JOMFSIP/article/view/15670

Anggraini, R. D. (2011). Pengaruh kepemilikan institusional dan kepemilikan asing terhadap pengungkapan pertanggungjawaban sosial perusahaan dalam annual report (studi empiris padaperusahaan non keuangan yang tercatat di BEI Tahun 2008-2009). Skripsi Universitas Diponogoro.http://eprints.undip.ac.id/26641/

Atmaja, L. S. (2008). Teori dan praktek manajemen keuangan. Jogjakarta: Penerbit Andi.

Crutchley, C. E., \& Hansen, R. S. (1989). A test of the agency theory of managerial ownership, corporate leverage, and corporate dividends. Financial Management, 18(4), 36-46. https://doi.org/10.2307/3665795

Djabid, A. W. (2009). Kebijakan dividen dan struktur kepemilikan terhadap kebijakan utang: Sebuah perspektif agency theory. Jurnal Keuangan Dan Perbankan, 13(2), 249259.http://jurnal.unmer.ac.id/index.php/jkdp/article/view/933

Guinan, J. (2010). Investopedia: Cara Mudah Memahami Istilah Investasi. Jakarta: Hikmah.

Indahningrum, R. P., \& Handayani, R. (2009). Pengaruh kepemilikan manajerial, kepemilikan institusional, dividen, perumbuhan perusahaan, free cash flow dan profitabilitas terhadap kebijakan hutang perusahaan. Jurnal Bisnis Dan Akuntansi, $11(3)$, 189-207.

DOI: https://doi.org/10.34208/jba.v11i3.244

Jensen, M. C. (1986). Agency costs of free cash flow, coporate finance and takeovers.American Economic

339.DOI:http://dx.doi.org/10.2139/ssrn.99580

Review, $\quad$ 76(2),323-

Jensen, M. C., \& Meckling, W. H. (1976). Theory of the firm: Managerial behavior, agency costs and ownership structure. Journal of Financial Economics 3(4), 305-360. DOI:https://doi.org/10.1016/0304-405X(76)90026-X

Mardiyati, U., Qothrunnada, Q., \& Kurnianti, D. (2018). Pengaruh kepemilikan manajerial, struktur aktiva, ukuran perusahaan, pertumbuhan penjualan dan profitabilitas terhadap kebijakan utang pada perusahaan sektor aneka industri yang terdaftar di Bursa Efek Indonesia (BEI) Periode 2012 - 2016. JRMSI - Jurnal Riset Manajemen Sains Indonesia, 9(1), 105-124.DOI: https://doi.org/10.21009/jrmsi.009.1.08 
Nafisa, A., Dzajuli, A., \& Djumahir. (2016). Pengaruh kepemilikan manajerial, kepemilikan institusional, ukuran perusahaan, pertumbuhan perusahaan, free cash flow dan profitabilitas terhadap kebijakan hutang perusahaan manufaktur di Bursa Efek Indonesia. Ekonomi Bisnis, 21(2), 122135.http://journal2.um.ac.id/index.php/ekobis/article/view/2022

Nasser, E. M. (2008). Pengaruh stuktur kepemilikan dan dewan komisaris independen terhadap nilai perusahaan dengan manajemen laba dan kebijakan hutang sebagai variabel intervening. Media Riset Akuntansi, Auditing Dan Informasi. 8(1), 1-27. DOI:https://doi.org/10.25105/mraai.v8i1.740

Putri, I. F., \& Nasir, M. (2006). Analisis persamaan simultan kepemilikan manajerial, kepemilikan institusional, risiko, kebijakan hutang dan kebijakan dividen dalam perspektif teori keagenan. Simposium Nasional Akuntansi 9 Padang, 2326.http://blog.umy.ac.id/ervin/files/2012/06/K-AKPM-18.pdf

Rozeff, M. S. (1982). Growth, beta and agency costs as determinants of dividend payout ratios. TheJournal of Financial Research, 5(3), 249-259. DOI:https://doi.org/10.1111/j.1475-6803.1982.tb00299.x

Setiana, E., \& Sibagariang, R. (2013). Pengaruh free cash flow dan kepemilikan manajerial terhadap kebijakan hutang pada perusahaan manufaktur yang terdaftar di Bursa Efek Indonesia (BEI). Jurnal Telaah Akuntansi (15)1, 16-33. http://digilib.unimed.ac.id/842/2/Full\%20Text.pdf

Sinaga, G. Y. (2017). Pengaruh pertumbuhan perusahaan, free cash flow , struktur aset, likuiditas, profitabilitas, dan risiko bisnis terhadap kebijakan hutang. Skripsi. https://lib.unnes.ac.id/29892/

Sitanggang. (2013). Manajemen Keungan Perusahaan Lanjutan. Edisi 2. Jakarta: Mitra Wacana Media.

Sugiarto. (2009). Struktur Modal, Struktur Kepemilikan Perusahaan, Permasalahan Keagenan dan Informasi Asimetri. Yogyakarta: Graha Ilmu.

Surya, D., \& Rahayuningsih, D. A. (2012). Faktor-faktor yang mempengaruhi kebijakan hutang perusahaan non keuangan yang terdaftar dalam Bursa Efek Indonesia. Jurnal Bisnis Dan Akuntansi, 14(3), 213225.https://jurnaltsm.id/index.php/JBA/article/view/143

Syamsuddin, L. (2009). Manajemen Keuangan Perusahaan. Jakarta: Graha Ilmu.

Wahidahwati. (2002). Pengaruh kepemilikan manajerial dan kepemilikan institusional pada kebijakan hutang perusahaan: sebuah perspektif theory agency. The IndonesianJournal of Accounting Research (IJAR), 5(1). http://www.ijariaikapd.or.id/index.php/ijar/article/view/67

Warapsari, A., \& Suaryana, I. (2016). Pengaruh kepemilikan manajerial dan institusional terhadap nilai perusahaan dengan kebijakan utang sebagai variabel intervening. $E$ Jurnal Akuntansi, 16(3), 22882315.https://ojs.unud.ac.id/index.php/Akuntansi/article/view/20974

Watts, R. L., \& Zimmerman, J. L. (1990). Positive accounting theory: A ten year perspective. The Accounting Review, 65(1), 131-156. https://www.jstor.org/stable/247880?seq=1 